\title{
Non-Native Teachers' Foreign Language Pronunciation Anxiety
}

\author{
Zdena Kralova, Eva Mala \\ Constantine the Philosopher University in Nitra, Slovakia
}

\begin{abstract}
The current study focuses on the link between the age of Slovak EFL teachers and their English pronunciation anxiety and English pronunciation quality. Data were collected by both qualitative (questionnaire and interview) and quantitative methods (scale and test). The correlation analysis revealed positive relationship between age and pronunciation anxiety and negative relationship between age and pronunciation quality which contradicts the traditional belief that the length of teaching experience is a factor reducing teachers' anxiety.
\end{abstract}

\section{Introduction}

Anxiety can be defined as a mental and physical state characterized by specific emotional, physical, cognitive and behavioural symptoms. It is an adaptive reaction which mobilizes organism and helps it defend, attack, or avoid an anxiety stimulus. Anxiety when associated with learning a foreign language is termed as "foreign language anxiety" (FLA) related to the negative emotional reactions of the learners towards foreign language acquisition [1].

FLA is generally viewed as a complex and multidimensional phenomenon of self-perceptions, beliefs, feelings and behaviours related to foreign language learning [1]. It can be viewed both as a stable characteristic trait and the temporary state caused by various factors. The classical study of Horwitz, Horwitz, and Cope [1] introduced a construct of FLA as a situation-specific anxiety aroused by a specific type of situation or event.

FLA is considered more of a psychological (identity-based) construct than a linguistic (competence-based) construct [2], stemming most likely from the learner's perception of "self", where self-perceptions, perceptions of others, perceptions of foreign language learning and performance play important roles [3]. Since researchers began recognizing affective factors as equally relevant in learning as cognitive factors in the second half of the twentieth century, FLA became one of the most examined affective variables in the field of foreign language learning.

Attempting to understand the overall process of foreign language learning, researchers have investigated the relationship of language learning and different lingual (related to the language system) and extra-lingual (related to the language learning process) variables [4]. Lingual factors can be subdivided into the intra-lingual and inter-lingual subcategories. Intra-lingual factors result from the system of a foreign language itself while the interlingual factors result from the contact of two language systems (mostly a native language and a foreign language) [4].

The extra-lingual factors are believed to affect FLA more intensively than the lingual factors. Numerous studies trying to identify the learning related variables of FLA most frequently recognized the categories of personal (intra-personal and interpersonal) and impersonal determinants [4]. The intrapersonal determinants of FLA result from learners' personal characteristics, their beliefs and attitudes within foreign language learning, while the interpersonal ones are bound to the inter-personal interactions (learner-teacher or learner-learner) during the learning process. The impersonal factors are related to non-personal aspects of foreign language learning.

From the temporal perspective, the static and the dynamic variables affecting FLA can be further distinguished within the extra-lingual factors. The static factors involve rather stable characteristics (gender, nationality, native language, type of personality, etc.) and the dynamic factors (such as language proficiency, motivation, and stay in a foreign language country) can change over time.

Most studies concluded that speaking is the skill most affected by FLA [5]. Speaking in a foreign language is often sensed as a "threat to peoples' selfconcept, self-identity, and ego, which they have formed in their first language as reasonable and intelligent individuals" [1]. Probably no other field of study implicates such a disparity between the "true self" and the "limited self" as foreign language learning. Learners' self-expression is limited by their 
imperfect command of a foreign language. Inability to present oneself according to one's self-image can set a learner into the cycle of negative self-evaluation as language and the self are intimately bound [1].

One of its most immediate determinants of speaking is the concern over foreign language pronunciation [6]. Pronunciation is seen as the most salient aspect of the language ego [7] and difficult to acquire in a new language. It is strongly related to human identity and the learner's level of selfconfidence. Moreover, pronunciation plays a dominant role in the way communication partners are viewed [8]. Therefore, the apprehension of one's ego being threatened in front of others can be rather strong source of FLA among foreign language learners [9].

However, a few experiments studying the foreign language pronunciation anxiety and verifying the strategies of its reduction have been conducted so far. Baran-Łucarz [10] investigated the effect of anxiety on learning foreign language phonetics (Phonetics Learning Anxiety) - which represents a significant step in understanding the impact of affective factors on pronunciation learning. Kralova et al. [11] tested the psycho-social training as a strategy reducing foreign language pronunciation anxiety among non-native pre-service teachers of a foreign language.

The correlational studies produced rather inconsistent results in determining the relationship between FLA and achievement in a foreign language - some studies found negative relationship between the anxiety and achievement; others found positive relationship, while others found no relationship at all. Horwitz, Horwitz, and Cope [1] made a valuable contribution not only to the theory but also to the measurement of FLA by their milestone work "Foreign Language Classroom Anxiety". They developed the most frequently used and adopted selfreport tool to measure FLA in a classroom setting the Foreign Language Classroom Anxiety Scale.

The universal scale by [1] has been later adjusted by other researchers according to the language or cultural background where the research has been conducted. Studies of FLA used mostly quantitative methods, applying correlational analysis where questionnaires and scales have been proved to be reliable instruments. From qualitative methods, mostly interviews of anxious learners were performed. It seems the correlational studies only will not provide a valid and reliable answer and indepth understanding of FLA complexity. The investigation thus should not be limited to either quantitative of qualitative methods. FLA as a complex human phenomenon needs to be explored in a holistic perspective and the solution seems to be the mixed methods research.

\section{Foreign Language Teachers}

Nearly all interventions attempting to reduce FLA are learner-oriented and rely on foreign language teachers to implement anxiety-relieving behaviours and practices in their classrooms. It is often forgotten that many foreign language teachers themselves are not native speakers and may face FLA as well [12]. E. K. Horwitz [12] using the Teacher Foreign Language Anxiety Scale, was the first researcher to propose that non-native teachers and student teachers may experience feelings of FLA. However, to this day, research on teachers' and student teachers' FLA is limited to more or less descriptive studies. Nevertheless, this kind of FLA can have rather an undesirable influence on foreign language learning. The role of a teacher is undoubtedly one of the most crucial ones in making foreign language learning less stressful and more enjoyable [12].

As teachers and learners constantly interact, the emotions of one group cannot be considered separately from the emotions of the other group. Teachers' FLA can have a number of undesirable effects on foreign language education [12]. As the number of non-native foreign language teachers increases by the year, it is clear that more research is desperately needed in this area. It was indicated that teachers' perceptions play an important role in students' FLA as teacher is the person in the classroom who can regulate the atmosphere, search for the signs of anxiety and help students overcome it. The classroom that follows traditional learning styles, its strictness and formality was declared as the major source of stress [13].

Foreign language teachers are supposed to be perfect foreign language speakers and much of their FLA stems from the inherent threat to their selfconcept of competence. High-level foreign language competence can be best achieved by intensive communication with native speakers or a longer stay in a foreign language country. In fact, not many nonnative foreign language teachers have access to this.

Though practice in teaching foreign language appears to be a viable strategy to reduce FLA [14], some kind of post-communist countries' paradox has to be mentioned in this context [15] corresponding to the previous findings that the high level of FLA is associated with older learners, who had never visited a foreign country [16]. More experienced Slovak teachers of English as a foreign language (EFL) often experience higher speaking anxiety due to the socio-political factors influencing their learning of English in the years of communism. The lack of communication in the authentic English language and limited opportunities to stay in an Englishspeaking country during the years in totalitarian regime caused higher communication inhibitions among teachers of English and other western foreign languages. 
The Velvet (or Gentle) Revolution was a nonviolent transition of power in Czechoslovakia (former federation of the Czech and Slovak Republic) in 1989. The result was the end of 41 years of communist rule and the conversion to the parliamentary democratic republic. Czechoslovakia has undergone many subsequent political, social, economic and other changes. Within the education system one of the most striking changes was the start of massive teaching and learning of western languages (especially English) as the study of western "capitalist" languages was more or less restricted till 1989 in communist countries (similar findings have been revealed in the Korean context [17]).

\subsection{Foreign Language Anxiety Coping Strategies}

Considerable scholarly attention has been paid to strategies to alleviate the anxiety of people in various situations and contexts for many years. Several anxiety workshops (e.g., the Foreign Language Anxiety Workshop at the Defense Institute in San Francisco, USA., in 1987); programs (e.g., the Support Group for Foreign Language Learning at the University of Texas at Austin, USA., operating since the 1980s) and clinics (e.g., the Science Anxiety Clinic at Loyola University, USA. in 1976) have been successfully implemented in various fields of education [18].

Within foreign language learning numerous FLA coping (reducing or management) strategies have been discussed. Already Horwitz [12] suggested a three-strategy approach as the most effective treatment including: systematic desensitization learning how to relax in the presence of anxiety stimuli; cognitive modification - changing learners' own cognitive appraisals and managing their selfevaluation; and skills training.

When verifying ways of reducing FLA, earlier studies focused on two primary strategies - skills development and behavioural therapy. The combination of these two strands was considered to be the best therapeutic approach. Many learners of foreign languages intuitively assume that the most effective "remedies" in relieving their FLA are cognitive (more intensive foreign language practice) and emotional (something which would reduce their psychological inhibitions regarding communication in a foreign language) [11].

Researchers have already verified strategies of various kinds where the remediation of FLA has focused mainly on three approaches - cognitive, affective and behavioural [19] according to the modality emphasized. Studies that verified the cognitive approach focused on changing learners' own cognitive appraisals and teaching learners more realistic self-evaluation. The affective approach is focused on reducing the negativity of the foreign language experience and includes therapies such as systematic desensitization, biofeedback, support groups, relaxation, meditation, engagement programs and recall techniques. The behavioural approach presumes that FLA occurs as a result of poor language skills, prompting the attempt to train learners in skills applying different methods and techniques.

FLA reducing strategies can also be classified according to whether they refer to either internal or external parts of the education process. Within the internal elements of the education process - a teacher and a learner, two types of FLA reducing strategies can be distinguished. Teaching strategies are applied by foreign language teachers to help their students learn a foreign language more effectively. Learning strategies are applied by foreign language learners consciously or subconsciously and they usually develop from their learning styles. Today, strategies external to the education process are intensively applied in line with the post-communicative approach in foreign language pedagogy integrating affective, cognitive and behavioural modalities of learning. Such intervention strategies are often led by psychologists in close cooperation with foreign language teachers.

\section{Methodology}

\subsection{Objectives}

The main objectives of the study were to find out whether there is any correlation between the English pronunciation anxiety (EPA), English pronunciation quality (EPQ) and the age of Slovak in-service EFL teachers; and what are their EPA self-perceived sources and effective coping strategies. Within the above-mentioned facts, the following research questions and hypotheses were formulated:

\section{Research questions}

1. What are the self-perceived sources of Slovak EFL teachers' English pronunciation anxiety (EPA)?

2. What are the self-perceived effective EPAcoping strategies of Slovak EFL teachers?

\section{Research hypotheses}

1. There is a positive correlation between the age and EPA of Slovak EFL teachers.

2. There is a negative correlation between the age and English pronunciation quality (EPQ) of Slovak EFL teachers.

3. There is a negative correlation between EPA and EPQ of Slovak EFL teachers. 


\subsection{Participants}

One hundred Slovak EFL in-service teachers divided into four age groups, each of 25 teachers: I ( $\leq 30$ years old), II (31-40 years old), III (41-50 years old) and IV ( $\geq 51$ years old) were selected by the stratified random sampling. The age-groups were defined according to the socio-political circumstances of English language learning within the Slovak context (see Results).

\subsection{Instruments}

3.3.1. Background questionnaire. The questionnaire was prepared in the participants' native language to obtain their relevant demographic data - age, gender, time and duration of English language study, type of English language study, quantity and quality of communication with English native speakers, and stay in English-speaking countries. These characteristics were identified as influencing for the analysed phenomena.

At the preliminary state of the background questionnaire design, a flow chart technique was used to plan sequencing of the questions. Then, the pilot was conducted on a group of 20 respondents with characteristics of the research sample who did not receive the final version. The questionnaire was refined and redundant items and items with low reliability were removed. The questionnaire was selfadministered by the authors to enable any queries to be addressed immediately. Finally, the coding system for the data analysis was created [20].

3.3.2. English Pronunciation Anxiety scale. The self-developed instrument called EPA scale (see Appendix) was used to examine the participants' English pronunciation anxiety level. They were given the English-specific pronunciation anxiety scale in their native language. The design of EPA scale was inspired by the Foreign Language Classroom Anxiety Scale [1] and the Phonetics Learning Anxiety Scale [10] and based on the authors' teaching experience in English phonetics courses.

The scale included 20 declarative statements to gather the participants' perceptions of their English pronunciation and required them to indicate the extent to which they agree/disagree with the statements based on a 5-point Likert scale. Points were related to varying degrees with 5 points representing "strongly agree", 4 points - "agree", 3 points - "undecided", 2 points - "disagree" and 1 point - "strongly disagree".

The EPA scale was structured into six subcomponents: oral performance apprehension (items 1-4), self-concern over pronunciation (items 5-8), pronunciation self-image (items 9-12), pronunciation self-efficacy (items 13-16) and attitude to English pronunciation (items 17-20). In five items a reversed scoring was used (see Appendix). The anxiety score ranged from 20 to 100 , with higher scores reflecting higher anxiety. The level of anxiety was classified in the following intervals: 20-40 minimum level; 41-60 - mild level; 61-80 moderate level; and 81-100 - high level.

3.3.3. English Pronunciation Quality test. In order to examine the English pronunciation proficiency, the participants' pronunciation samples (a free, extemporaneous talk in English of 2.8 minutes on average) were recorded. To establish the reliability of measuring, three British native speakers of English conducted the subjective auditory evaluation of the participants' English pronunciation quality using the equal-appearing interval 5-point Likert scale (5 - excellent; 4 - very good; 3 - quite good; 2 - not very good; 1 - poor). The scale reflects the extent to which the participants' accent diverges from the British English pronunciation norms.

3.3.4. Semi-structured interview. A semi-structured interview was used in conjunction with other methods to go deeper into the participants' selfperceptions and experience concerning their English pronunciation. First, the research objectives were transformed into two direct form questions and specified two variables - the sources of participants' EPA and the assistance they would appreciate to improve their EPQ and to reduce their EPA.

The interviews were conducted by the authors with twenty-five highest-anxiety participants to find out their perspective on the variables stated. The interviewers considered also some prompts to clarify their questions and probes to ask respondents to provide details for their response, if needed. Respondents were enabled to answer the questions in their own words and thus produced unstructured responses.

The interview was conducted in a face-to-face format. The interviewers informed each participant about the purpose and conduct of the interview and asked for permission to record the responses. The interviews were then transcribed and analysed by generating and classifying natural units of meaning set into categories. The frequencies of occurrence were counted and regularities followed [20].

\subsection{Procedure}

This mixed-method study applied both the qualitative methods (questionnaire and interview) and quantitative methods (scale and test). The data were collected and evaluated, and the individual scores of the respective parts were analysed using descriptive statistics and non-parametric tests to examine the correlation between the participants' age, EPA and EPQ scores. 
The EPA score for each participant was computed by summing up the scores of each questionnaire item. The EPQ score for each participant was computed by averaging the raters' scores. The data obtained were submitted to a correlation analysis using the Spearman's Rank Correlation Coefficients $(R)$ to discern whether the participants' EPA and EPQ correlate with their age.

\section{Results}

\subsection{Background questionnaire}

The age-group I members were born after the Velvet Revolution in 1989 and most of them started learning English in kindergartens, i.e. during their critical age for learning foreign languages (before 46 years of age). Later on, they had unlimited opportunities to travel and stay abroad, to meet English native speakers or watch and listen to English mass media.

Most of the age-group II teachers started learning English at primary schools (after 6 years of age) and the age-group III teachers usually started learning English at secondary schools (after 14-15 years of age) or at universities (after 18 years of age).

The age-group IV participants had restricted contact with English culture and native speakers and not many of them could study English within the Slovak educational system. Most of them completed their English language study within continuing teacher education during their in-service teaching. However, after 1989 they often had other personal or economical limits to travel to or stay in English speaking countries for a long time.

\subsection{English Pronunciation Anxiety scale}

First, the means of the self-reported anxiety levels were calculated for each age-group (see Table 1). The highest scores were obtained in the age-group IV and the lowest scores in the age-group I.

Table 1. EPA scores in the age-groups

\begin{tabular}{|c|c|c|}
\hline Age group & EPA mean & EPA level \\
\hline IV & 68.8 & moderate \\
\hline III & 61.4 & moderate \\
\hline II & 45.8 & mild \\
\hline I & 29.8 & minimum \\
\hline
\end{tabular}

\subsection{English Pronunciation Quality test}

An EPQ rating was obtained from each native speaker for each participant. The Friedman NonParametric Test showed an acceptable level of internal reliability of their ratings $(p=0.94892, \alpha=$ 0.05). Therefore, the group scores could be computed by averaging across each rater's score for each participant (see Table 2).

Table 2. EPQ scores in the age-groups

\begin{tabular}{|c|c|c|}
\hline Age group & EPQ mean & EPQ level \\
\hline IV & 2.8 & quite good \\
\hline III & 3.6 & very good \\
\hline II & 4.5 & excellent \\
\hline I & 4.1 & very good \\
\hline
\end{tabular}

\subsection{Correlation}

Table 3 displays the Spearman's Rank Correlation Coefficients $(R)$ achieved between the participants' age, EPA and EPQ. As the table shows, a high positive correlation $(0.70 \leq|R|<0.90)$ was found between the age and EPA, a strong negative correlation $(0.5 \leq|R|<0.7)$ between the age and EPQ and a negative correlation of moderate strength $(0.30$ $\leq|R|<0.50)$ was detected between EPA and EPQ. Figures 1 and 2 compare the relationship between the participants' age and EPA/EPQ.

Table 3. Correlation of age, EPA and EPQ

\begin{tabular}{|c|c|c|c|}
\hline$R$ & Age & EPA & EPQ \\
\hline Age & - & 0.8737 & -0.5974 \\
\hline EPA & 0.8737 & - & -0.4672 \\
\hline$E P Q$ & -0.5974 & -0.4672 & - \\
\hline
\end{tabular}

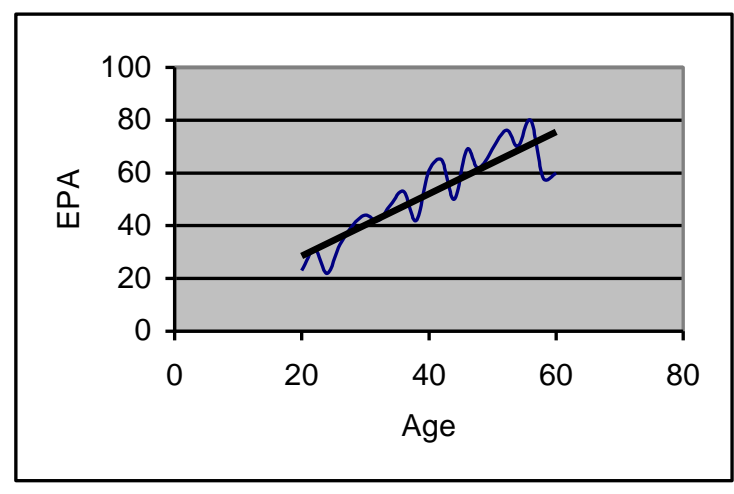

Figure 1. Age and EPA relationship 


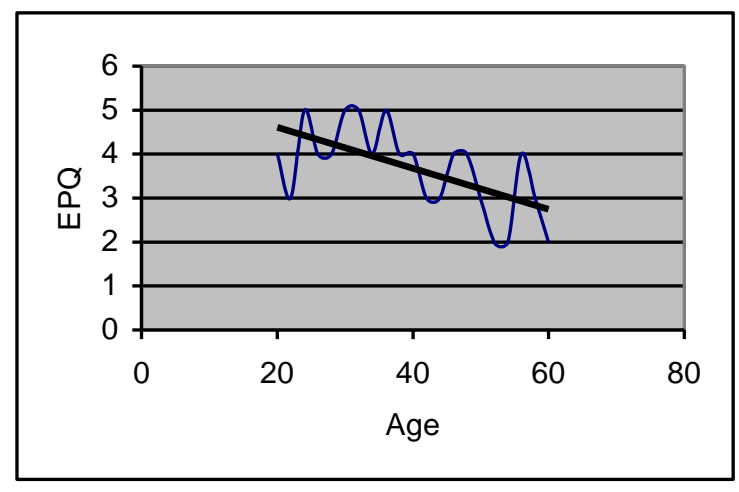

Figure 2. Age and EPQ relationship

\subsection{Semi-structured interview}

The interviews with 25 highest-anxiety teachers revealed that the primary source of their EPA is the self-perceived inadequate and non-native like English pronunciation and the self-perceived importance of good pronunciation for English teachers. Many of them believe that pronunciation is the most important aspect of English language learning expressing a great concern for speaking with a native-like accent

The scale items most strongly reflecting their EPA were no. 6 (I am bothered about making pronunciation mistakes), no. 7 (I realize how many pronunciation mistakes I make) and no. 20 (I think that good English pronunciation is very important for an English teacher).

The high-anxious participants consider intensive and frequent communication in English, ideally with a native-speaker, the best EPA-reducing strategy. They would also appreciate some kind of psychological training to eliminate their inhibitions to speak in English.

\section{Discussion}

The research data obtained indicated that the socio-lingual aspects of learning English cannot be ignored. The lack of opportunities to travel to and stay in English-speaking countries and to communicate with English native speakers were reported as the strongest drawbacks and reasons of inadequate EPQ by the Slovak EFL teachers.

In the interviews, most of the teachers reported strong speaking anxiety and indicated inadequate English pronunciation as the strongest barrier in speaking. They were afraid of being ridiculed and not accepted as an authority by their students. The highest level of EPA was detected in the group of EFL teachers who did not have adequate learning opportunities in their young years before 1989, and the lowest level of EPA was reported by the teachers who were born after 1989 and thus had an unrestricted access to the English language and culture from the very beginning.

The most critical age of Slovak EFL teachers today is thus over 50 years of age. Many of them lack motivation to study and improve their English pronunciation though they sense it as unsatisfactory. As a result, their most frequent coping strategy is the avoidance behaviour - they try to avoid spontaneous and continuous speaking activities in their classrooms, which is rather harmful and in fact impossible in modern teaching and learning a foreign language. Moreover, EFL teachers over 50 will be teaching for more than ten years on.

Teaching today is extremely demanding, both cognitively and emotionally. Students are likely to sense their teachers' uncertainty in a foreign language so the teachers should be supported to cope with their problems (including FLA) prior to and during their teaching career, so that they will be able to manage their own FLA and FLA of their students.

All three research hypotheses formulated were proved:

1. There is a positive correlation between the age and EPA of Slovak EFL teachers which means that the older the EFL teachers are, the more they suffer from EPA. Nevertheless, their EPA was of moderate strength and not of the highest level determined.

2. There is a negative correlation between the age and EPQ of Slovak EFL teachers. However, this relationship is not perfectly linear as the highest level of EPQ was observed in the age-group II (31-40 years old), not among the youngest EFL teachers. What is more, none of the groups' EPQ was evaluated as poor. Even the age-group IV reporting highest EPA reached quite-good level of EPQ.

3. There is a negative correlation between EPA and EPQ of Slovak EFL teachers. In other words, the higher pronunciation anxiety, the lower pronunciation quality and vice versa. However, this proportion was only of the moderate strength.

Most Slovak EFL teachers intuitively assume that the most effective remedies in relieving their English pronunciation anxiety take two forms - behavioural ("more intensive English pronunciation practice") and affective ("something which would reduce our psychological inhibitions to speak English").

Modern trends in teaching foreign languages emphasize an affective aspect of learning to counterbalance the cognitive aspect and many researchers (e.g., [11] and [12]) have already acknowledged the need of FLA coping training for foreign language learners as a supplement to skills training.

\section{Conclusions}

Teacher holds the major responsibility for the learning atmosphere in a classroom. FLA can 
negatively influence teacher's use of communicative teaching practices, willingness to seek out improvement opportunities, an overall well-being and job satisfaction [1]. As the current findings indicate, teaching experience does not go hand in hand with low anxiety and good foreign language command. This study is expected to have implications not only for the teaching and learning of English pronunciation but also for the modification of foreign language teacher training curricula, in which a focus on psycho-social aspects concerning teachers should be incorporated. Targeted teacher training reflecting their problems ought to be carefully planned and included into continuing teacher education.

Foreign language learning is a life-long commitment [12], so it should be the main objective of methodologists to find the most efficient methods for foreign language learning and teaching. They should take into consideration the real needs of learners and teachers, thus making the learning of foreign language more effective, enjoyable and less frustrating. Moreover, English plays an important role in the global market as it is a communication language of business, education, science and technology and an effective oral communication is seen as a socially valued skill.

\section{Limitations}

The overall findings of this study indicate a strong relationship between the teachers' age and EPA in Slovakia as a post-communist country. However, these findings must be interpreted in the light of several limitations.

The first one is the space limit, which precluded publishing data on all parts of the experiment in a single article. The study presents partial data from a larger longitudinal study including laboratory measurements of pronunciation. Collectively, the data gathered could offer additional perspectives on the issue.

The second limitation is the small sample size. Though the groups showed clear tendencies in the data, larger groups may allow group distinctions to emerge more clearly.

Finally, future research may want to verify the issue in other countries with similar socio-political and historical background. In spite of these limitations, it is hoped that another small step has been taken towards a greater understanding of special needs of foreign language teachers.

\section{Acknowledgements}

Our thanks go to all teachers participating in the research that was funded by the Scientific Grant Agency of the Ministry of Education, Science,
Research and Sport of the Slovak Republic (VEGA 1/0062/17).

The paper was presented at the World Congress on Special Needs Education (WCSNE 2017) Inclusive Education held in Cambridge, UK (December 11-14, 2017).

\section{References}

[1] E. K. Horwitz, M. B. Horwitz, and J. A. Cope, "Foreign language classroom anxiety", The Modern Language Journal, 70, 1986, pp. 125-132.

[2] F. Alrabai, "The influence of teachers' anxietyreducing strategies on learners' foreign language anxiety", Innovation in Language and Teaching, 9, 2015, pp. 163190.

[3] T. Scovel, "The effect of affect on foreign language learning: A review of the anxiety research", In E. K. Horwitz, and D. J. Young (Eds.), Language anxiety: from theory and research to classroom implications. Englewood Cliffs: Prentice Hall, 1991.

[4] Z. Kralova, The Factors of English Phonic Competence. Zilina: EDIS, 2009.

[5] E. K. Horwitz, "Research timeline. Foreign and second language anxiety", Language Teaching, 43, 2010, pp. 154167.

[6] M. Baran-Łucarz, "The relationship between language anxiety and the actual and perceived levels of foreign language pronunciation", Studies in Second Language Learning and Teaching, 1, 2011, pp. 491-514.

[7] A. Guiora, B. Beit-Hallahmi, R. C. L. Brannon, C. Y. Dull, and T. Scovel, "The effects of experimentally induced changes in ego states on pronunciation ability in a second language: An exploratory study", Comprehensive Psychiatry, 13, 1972, pp. 139-150.

[8] S. Lev-Ari, and B. Keysar, "Why don't we believe non-native speakers? The influence of accent on credibility", Journal of Experimental Social Psychology, 46, 2010, pp. 1093-1096.

[9] M. Baran-Łucarz, "Pronunciation anxiety and willingness to communicate in the foreign language classroom", Concordia Working Papers in Applied Linguistics, 5, 2014, pp. 36-49.

[10] M. Baran-Łucarz, "Phonetics learning anxiety results of a preliminary study", Research in Language, 11.1, 2013, pp. 57-79.

[11] Z. Kralova, E. Skorvagova, A. Tirpakova, and D. Markechova, "Reducing student teachers' foreign language pronunciation anxiety through psycho-social training", System, 65, 2017, pp. 49-60.

[12] E. K. Horwitz, "Even teachers get the blues: Recognizing and alleviating teachers' feelings of foreign 
language anxiety", Foreign Language Annals, 29, 1996, pp. 365-372.

[13] K. Ohata, "Potential sources of anxiety for Japanese learners of English: Preliminary case interviews with five Japanese college students in the U.S.", TESL-EJ, 9, 2005, pp. 1-21.

[14] L. L. Morton, R. Vesco, N. H. Williams, and M. A. Awender, "Student teacher anxieties related to class management, pedagogy, evaluation, and staff relations", British Journal of Educational Psychology, 67, 1997, pp. 69-89.

[15] Z. Kralova, Foreign Language Anxiety. Nitra: UKF v Nitre, 2016.

[16] A. J. Onwuegbuzie, P. Bailey, and C. E. Daley, "Factors associated with foreign language anxiety", Applied Psycholinguistics, 20, 1999, pp. 217-239.

[17] S.-Y. Kim, and J. Kim, "When the learner becomes a teacher: Foreign language anxiety as an occupational hazard", English Teaching, 59, 2004, pp. 165-184.

[18] Campbell, C. M., and Ortiz, J. A. "Helping students overcome foreign language anxiety: A foreign language anxiety workshop." In E. K. Horwitz, and D. J. Young (Eds.), Language anxiety: from theory and research to classroom implications. Englewood Cliffs: Prentice Hall, 1991.

[19] Kondo, D. S., and Ying-Ling, Y. "Strategies for coping with language anxiety: the case of students of English in Japan”, ELT Journal, 58, 2004, pp. 258-265.

[20] L. Cohen, L. Manion, and K. Morrison, Research methods in education. $6^{\text {th }}$ edition. New York: Routledge, 2007.

\section{Appendix A \\ English Pronunciation Anxiety Scale}

(Please, cross the answer.)

1. I do not feel nervous when speaking English. (reverse-scoring)

$\square$ strongly agree

$\square$ agree

$\square$ undecided

$\square$ disagree

$\square$ strongly disagree

2. I do not like talking to more advanced English speakers.

$\square$ strongly agree

$\square$ agree

$\square$ undecided

$\square$ disagree

$\square$ strongly disagree

3. I feel embarrassed talking to people with good English pronunciation.

$\square$ strongly agree

$\square$ agree $\square$ undecided

$\square$ disagree

$\square$ strongly disagree

4. I get nervous when I have to speak English in front of other people.

$\square$ strongly agree

$\square$ agree

$\square$ undecided

$\square$ disagree

$\square$ strongly disagree

5. I am satisfied with my English pronunciation. (reverse-scoring)

$$
\begin{aligned}
& \square \text { strongly agree } \\
& \square \text { agree } \\
& \square \text { undecided } \\
& \square \text { disagree } \\
& \square \text { strongly disagree }
\end{aligned}
$$

6. I am bothered about making pronunciation mistakes in English.

$\square$ strongly agree

$\square$ agree

$\square$ undecided

$\square$ disagree

$\square$ strongly disagree

7. I realize how many pronunciation mistakes I make.

$\square$ strongly agree

$\square$ agree

$\square$ undecided

$\square$ disagree

$\square$ strongly disagree

8. Ifeel embarrassed when I realize that I pronounce some words incorrectly. $\square$ strongly agree

$\square$ agree

$\square$ undecided

$\square$ disagree

$\square$ strongly disagree

9. I am afraid people will think I am silly and incompetent because of my poor English pronunciation.

$\square$ strongly agree

$\square$ agree

$\square$ undecided

$\square$ disagree

$\square$ strongly disagree

10. I consider imitating native-like English pronunciation ridiculous.

$\square$ strongly agree

$\square$ agree

$\square$ undecided

$\square$ disagree

$\square$ strongly disagree 
11. I am afraid my students have better English pronunciation than I do.

$\square$ strongly agree

$\square$ agree

$\square$ undecided

$\square$ disagree

$\square$ strongly disagree

12. Other English teachers do not have better English pronunciation than I do. (reversescoring)

$\square$ strongly agree

$\square$ agree

$\square$ undecided

$\square$ disagree

$\square$ strongly disagree

13. I am worried about not being understood because of my improper pronunciation.

$\square$ strongly agree

$\square$ agree

$\square$ undecided

$\square$ disagree

$\square$ strongly disagree

14. I do not feel ashamed when people correct my pronunciation mistakes. (reverse-scoring)

$\square$ strongly agree

$\square$ agree

$\square$ undecided

$\square$ disagree

$\square$ strongly disagree

15. It seems to me that I cannot get rid of my

Slovak accent in English.

$\square$ strongly agree

$\square$ agree

$\square$ undecided

$\square$ disagree

$\square$ strongly disagree

16. I can never master good English pronunciation. $\square$ strongly agree

$\square$ agree

$\square$ undecided

$\square$ disagree

$\square$ strongly disagree

17. I do not think English pronunciation is difficult. (reverse-scoring)

$\square$ strongly agree

$\square$ agree

$\square$ undecided

$\square$ disagree

$\square$ strongly disagree

18. I consider the rules of English pronunciation incomprehensible.

$\square$ strongly agree

$\square$ agree

$\square$ undecided

$\square$ disagree

$\square$ strongly disagree
19. It is very difficult to pronounce like a native speaker.

$\square$ strongly agree

$\square$ agree

$\square$ undecided

$\square$ disagree

$\square$ strongly disagree

20. I think that good English pronunciation is very important for an English teacher.

$\square$ strongly agree

$\square$ agree

$\square$ undecided

$\square$ disagree

$\square$ strongly disagree 